\title{
ATSAKINGO PRANEŠIMO APIE SAVIŽUDYBES REKOMENDACIJŲ RAIŠKA LIETUVOS ŽINIASKLAIDOJE
}

\author{
Kristina Balevičiūtè \\ Vilniaus visuomenès sveikatos centro \\ Visuomenès sveikatos saugos kontrolès skyrius \\ Kalvarijų g. 153, LT-08221 Vilnius, Lietuva \\ Telefonas (+370 6) 5924745 \\ Elektroninis paštas kristina.baleviciute@vilniausvsc.sam.lt \\ Aldona Jociutè \\ Mykolo Romerio universiteto Politikos ir vadybos fakulteto \\ Politikos mokslų institutas \\ Valakupių g. 5, LT-10101 Vilnius, Lietuva \\ Telefonas (+370 6) 8245780 \\ Elektroninis paštas joaldona@mruni.eu \\ Pateikta 2014 m. rugsèjo 4 d., parengta spausdinti 2014 m. spalio $10 \mathrm{~d}$. \\ doi:10.13165/SPV-14-2-7-06
}

\section{Santrauka}

Straipsnyje atskleidžiama visuomenès informuotuma skatinanti politika savižudybiu prevencijos srityje ir jos raiška žiniasklaidoje. Analizuojama, kaip Lietuvos spaudoje ir internetiniuose portaluose pateikiamuose pranešimuose apie savižudybes ir bandymus nusižudyti laikomasi specialistu rekomendaciju, skirtu šviesti ir informuoti visuomene apie savižudybes ir psichologinés pagalbos galimybes bei prevencijos priemones. Taip pat analizuojama, ar atsižvelgiama $i$ rekomendacijas dèl pranešimo pobūdžio, iliustravimo nuotraukomis ar vaizdo medžiaga, identifikacijos duomenu minèjimo pranešime bei pranešimų dèl visuomenei žinomo žmogaus savižudybès ar bandymo nusižudyti.

Nustatyta, kad specialistu parengtos rekomendacijos taikomos tik iš dalies. Visiškai neatsižvelgiama ị rekomendaciją šviesti ir informuoti visuomenę apie psichologines pagalbos galimybes, prevencines priemones, kaip atpažinti savižudišku minčiu turintị asmenị ir kokią pagalba jam pasiūlyti. Dažnai pasinaudojama vi- 
suomenei žinomo žmogaus savižudybe ir ji pateikiama sensacinga ir intriguojanti naujiena.

Reikšminiai žodžiai: atsakingas pranešimas, savižudybiu prevencijos politika, pranešimai apie savižudybes žiniasklaidoje, visuomenés informavimas.

\section{İvadas}

Formuojant politiką savižudybių mažinimo srityje svarbus vaidmuo tenka žiniasklaidai.

Viena iš specifinių iniciatyvų, atsižvelgiančių ị ịvairias Bendrijos politikos sritis, skirta informacinès visuomenès ir žiniasklaidos politikai ${ }^{1}$. Pasaulio sveikatos organizacijos (toliau - PSO) Psichinès sveikatos veiksmų plane 2013-2020 metams pabrèžiama savižudybių prevencijos prioriteto svarba ir atsakingas žiniasklaidos atstovų informacijos pateikimas².

2003 metais Lietuvos Respublikos Vyriausybès patvirtintoje Savižudybių prevencijos 2003-2005 metų programoje jau buvo akcentuojama, kad žinybos ir visuomenè nebegali veikti izoliuotai ${ }^{3}$. Vienas iš sektinų šios programos iggyvendinimo rezultatų - sustiprintas visuomenès informavimo priemonių vaidmuo savižudybių prevencijoje. Taip pat programos tiksluose įvardinta visuomenès informavimo priemonemis skleisti informaciją, ugdyti nuostatą, kad savižudybės galima išvengti, bei nuolat teikti informaciją apie prevencijos priemones, psichologinę pagalbą teikiančias organizacijas ir pagalbos būdus sau ${ }^{4}$.

PSO savižudybių prevencijos specialistai, psichologai yra parengę rekomendacijas žurnalistams ir leidejams, kaip atsakingai rengti ir skleisti informaciją apie savižudybes.

Rekomendacijos gali pakeisti rašymo apie savižudybes būdą ir stilių ir taip apsaugoti nuo imitacijos sindromo pasireiškimo, tačiau tik bendradarbiaujant, teikiant konsultacijas ir rengiant mokymus bus pasiekta didžiausia nauda ${ }^{5}$. Nustatyta, kad naudojimasis rekomendacijomis yra veiksminga priemonė pateikiant informaciją apie savižudybes ${ }^{6}$.

1 Europos Bendrijų Komisija. Žalioji knyga. Gyventojų psichikos sveikatos gerinimas. Europos Sąungos psichikos sveikatos strategijos kūrimas. Briuselis, 2005, p. 6.

2 Mental health action plan 2013-2020. World Health Organization [interaktyvus]. 2013, p. 17 [žiūrèta 2014-01-22]. <http://www.who.int/mental_health/action_plan_2013/en/index.html>.

3 Lietuvos Respublikos Vyriausybès nutarimas „Dèl savižudybių prevencijos 2003-2005 metų programos patvirtinimo“. Valstybès žinios. 2003, Nr. 36-1575.

4 Ibid.

5 Bohanna, I.; Wang, X. Media guidelines for the responsible reporting of suicide: a review of effectiveness. Crisis [interaktyvus]. 2012, 33(4) [žiūrèta 2014-01-26]. <http://www.ncbi.nlm. nih.gov/pubmed/22713977>.

$6 \quad \mathrm{Fu}, \mathrm{K}$. W; Jip, P. S. Changes in reporting of suicide news after the promotion of the WHO media recommendations", Suicide Life Threat Behav. 2008, 38(5). 
Specialistų teigimu, turètų būti ịstatymiškai reglamentuojama, kaip pateikti žinias apie savižudybes žiniasklaidoje, kad imitacijos efekto tikimybė būtų kuo mažesnè7. Tokios apibrèžtos taisyklès taikomos kai kuriose pasaulio šalyse ir būtų naudingos Lietuvoje, kur savižudybių skaičius didžiausias Europoje. Anot Jastramskio, kol savižudybių netinkamo pateikimo kriterijai žiniasklaidoje yra apibrežti tik rekomendacijomis ir neturi jokio teisinio pagrindo, patiems žurnalistams ir leidejjams paliekama spręsti, kokio turinio publikacijas ir vaizdo medžiagą pateikti visuomenei ${ }^{8}$.

PSO 2008 metų pranešimo apie savižudybes rekomendacijose žiniasklaidos profesionalams ${ }^{9}$ pažymima, kad pirmiausiai reikètų pasinaudoti galimybe šviesti visuomenę apie savižudybes bei vengti pateikti jas sensacingai arba kaip normalų dalyką. Taip pat nederètų detaliai ir išsamiai aprašinèti savižudybės, minèti būdą, vietą ar poelgio motyvus. Antraštes reikètų parinkti gan apdariai, o filmuotos ar fotografuotos medžiagos geriau visai nenaudoti. Dar vienas svarbus dalykas - turètų būti pateikiama informacija apie pagalbos suteikimą.

Kaip etiškai pateikti informaciją apie savižudybę žiniasklaidoje, nusako Lietuvos žurnalistų ir leidejų etikos kodekso ${ }^{10} 49$ straipsnis: „Žurnalistas, viešosios informacijos rengejjas, gerbdamas asmens ir jo artimųjų privatumą, neturi minèti pavardžiu ar kitokių šș asmenị (ypatingai nepilnametị) padedančių identifikuoti duomenų, susijusių su savižudybe ar bandymu nusižudyti. Skelbdamas informaciją apie savižudybes ar bandymus nusižudyti, žurnalistas, viešosios informacijos rengejas turi itin atsargiai nurodyti savižudybès ar bandymo nusižudyti motyvus bei aplinkybes, kad paskelbtoje informacijoje nebūtų skatinamas savižudiškas (suicidinis) elgesys visuomenèje. Skelbiant tokią informaciją, pageidautina pranešti apie esamą arba teikiamą psichologinę-socialinę pagalbą." Lietuvos radijo ir televizijos komisija yra parengusi „Rekomendaciją viešosios informacijos rengejams dèl informacijos apie savižudybes pateikimo“, kuria norima paskatinti ir motyvuoti viešosios informacijos rengèjus laikytis atsakingo informavimo apie savižudybes nuostatų, apsaugant nepilnamečius bei kitus ypač pažeidžiamus žmones nuo galimos žalos bei atsižvelgiant ị tai, kad žiniasklaida ne tik informuoja visuomenę, bet ir formuoja nuostatas bei vertybes, darančias itaką žmonių elgesiui ${ }^{11}$.

Kusta, A. Savižudybiu aprašymai gali paskatinti savižudybę. Jaunino psichologinès pagalbos centras [interaktyvus]. [žiūrèta 2014-0-01. <http://www.jppc.lt/?p=140\&lng=lt >.

8 Jastramskis, D. Savavališkos mirties paskatos žurnalistikoje. Žurnalistikos tyrimai. Komunikacija ir informacija. 2012, 5: 32.

9 World Health Organization. Preventing Suicide: A Resource for Media Professionals. Geneva: WHO Document Production Services, 2008, p. 6.

10 Lietuvos žurnalistų ir leidejų etikos kodeksas. Vilnius, 2005.

11 Lietuvos radijo ir televizijos komisijos nutarimas „Rekomendacija viešosios informacijos rengejjams dèl informacijos apie savižudybes pateikimo" [interaktyvus]. 2011, Nr. N-20 [žiūrèta 2014-02-29]. $<$ http://www.rtk.lt/assets/files/Rekomendacija_Del\%20informacijos\%20pateikimo\%20apie\%20 savizudybes-1\%281\%29.pdf>. 
Nors rekomendacijos savižudybės temomis rašantiems žiniasklaidos atstovams yra nuolat pateikiamos, tačiau jų efektyvumas mažai vertintas. Scotas ir Guo, atlikę sisteminę mokslinių publikacijų suicidine tema apžvalgą, nustatė, kad didesnę pusę sudaro tyrimai, kuriuose analizuojamas gydymas lyginant su prevencija ${ }^{12}$.

Siekiant pagrịsti rekomendacijų, skirtų teikiantiems informaciją apie savižudybes, naudojimosi efektyvumą, atliktas tyrimas, kurio rezultatai parodé, kad žurnalistų sąmoningumas, naudojimasis rekomendacijomis ir požiūris ị jas yra menkas. Indijoje atliktas tyrimas parodè, kad žiniasklaidos atstovų švietimas, kaip atsakingai pateikti informaciją apie savižudybes, pagerina pranešimų ko$\mathrm{kybę}^{13}$. Kadangi rekomendacijomis galima vadovautis pasirinktinai, paliekama pačiam žurnalistui ir leidejjui spręsti, kokią ir kaip informaciją pateikti. Tyrimu siekta nustatyti, kiek svarbūs žiniasklaidos atstovams yra rekomendacinio pobūdžio dokumentai ir ar atsižvelgiama ị juos rašant ir pateikiant visuomenei informaciją apie savižudybes ir bandymus nusižudyti.

Šiame straipsnyje pateikiamo tyrimo tikslas - ivertinti, kaip laikomasi atsakingo pranešimo apie savižudybes rekomendacijų Lietuvos žiniasklaidoje. Tyrimu siekiama nustatyti, ar visuomenès informavimo šaltiniuose atsižvelgiama ị savižudybių prevencijos specialistų pateikiamas rekomendacijas, susijusias su visuomenès švietimu ir informavimu apie savižudybes ir psichologinès pagalbos galimybes bei galimas prevencijos priemones. Taip pat ar atsižvelgiama $\mathfrak{i}$ rekomendacijas dèl pranešimo pobūdžio, iliustravimo nuotraukomis ar vaizdo medžiaga, identifikacijos duomenų minèjimo pranešime bei pranešimų dèl visuomenei žinomo žmogaus savižudybės ar bandymo nusižudyti.

\section{Tyrimo medžiaga ir metodai}

Tyrimui pasirinkti trys didžiausi pagal tiražą Lietuvos laikraščiai ir lankomiausios interneto svetainès. Remiantis Lietuvos Respublikos kultūros ministerijos 2012 metų pirmo pusmečio duomenimis, didžiausio tiražo laikraščiai Lietuvoje yra šie: savaitraštis „15 min“- 84250 egz., dienraštis „Vakaro žinios” 52521 egz., laikraštis „Lietuvos rytas” - 49566 egz..14. Lankomiausios internetinès svetainès: Delfi.lt, Lrytas.lt, 15 min.lt ${ }^{15}$.

12 Scott, A.; Guo, B. For which strategies of suicide prevention is there evidence of effectiveness? HEN synthesis report. World Health Organization, 2012, 33 p.

13 Ramadas, S.; Kuttichira, P. The development of a guideline and its impact on the media reporting of suicide. Indian Journal of Psychiatry [interaktyvus]. 2011, 53(3) [žiūrèta 2014-09-02]. <http:// www.ncbi.nlm.nih.gov/pubmed/22135440>.

14 Lietuvos Respublikos kultūros ministerija, Viešosios informacijos rengèjų ir skleidèjų duomenų bazè [žiūrèta 2014-02- 09]. <http://www.lrkm.lt/go.php/lit/Visuomenes_informavimo_politika/206>.

15 Gemius Baltic [žiūrèta 2014-02-29]. <http://www.e-lietuva.net/2013/01/29/lankomiausi-tinklapiailietuvoje-2012-metu-pabaigoje/>. 
Vertinti pasirinkta dvejų metų duomenys nuo 2012 sausio 1d. iki 2013 gruodžio 31d. Atliekant internetinę straipsnių ir pranešimų paiešką buvo naudojami raktažodžiai visame tekste: „savižudybë“, „nusižudë“, „žudytis“. Susidurta su tam tikrais keblumais, kadangi internetinių svetainių paieškos sistemos šiek tiek skiriasi. Internetinèse svetainèse $15 \mathrm{~min}$.lt bei Delfi.lt, pasirinkus raktažodị, paiešką galima atlikti tik pagal „naujumą“ arba pagal „aktualumą“. Dèl to tam tikri pranešimai, pateikti iki 2012 rugsèjo mèn., galèjo būti nerasti. Taip pat nuo 2013 m. liepos mènesio atsisakyta laikraščio „15 min.“ spausdinto varianto, leidžiama tik elektroninè laida. Dar vienas ịdomus dalykas, kad laikraštyje „15 min“ pasirinktu laikotarpiu nebuvo publikuota nė vieno pranešimo apie savižudybę.

Atliekant straipsnių turinio analizę, remtasi Lietuvos žurnalistų ir leidejjų etikos kodeksu ir 2008 metų PSO atsakingo pranešimo apie savižudybę rekomendacijomis žiniasklaidos profesionalams. Remiantis šiomis rekomendacijomis išskirti 8 kriterijai, pagal kuriuos buvo atliekama pranešimų turinio analizė:

1. ar minima susijusio su savižudybe ar bandymu nusižudyti asmens pavardè ar kiti padedantys ji identifikuoti duomenys;

2. detalus pranešimo turinys: nurodomi savižudybès aplinkybès motyvai, būdas ar vieta;

3. ar straipsnis iliustruotas nuotraukomis, vaizdo medžiaga;

4. ar nusižudęs ar bandęs žudytis žymus žmogus;

5. ar spausdinama pirmajame laikraščio puslapyje;

6. publikacijos pobūdis:

- neutralus, santūrus, pateikiami tik faktai;

- sensacingas, kaip normalus dalykas, problemos sprendimo būdas;

- romantizuojantis, heroizuojantis;

7. antrašte:

- ar pavadinime vartojamas žodis „savižudybë“,

- metodas,

- vieta;

8. ar yra nuorodos ị psichologinę pagalbą.

Remiantis minètais kriterijais analizei atrinkti 332 pranešimai apie savižudybes ir pasikèsinimus nusižudyti. Duomenys pateikiami procentine išraiška. Atliekant pranešimų apie savižudybes ar bandymus nusižudyti analizę, psichologiniai straipsniai, straipsniai apie savižudybių aktualumą, prevencijos problemas ir pan. į analizę neįtraukti. 


\section{2. Žiniasklaidoje pateikiami pranešimai apie savižudybę ar bandymą nusižudyti}

\subsection{Publikacijos skaičius, antraštė bei asmenị identifikuoti padedančių duomenų minẻjimas pranešime}

1 paveiksle galima matyti pranešimų, publikuotų per pasirinktąji laikotarpi populiariausiuose Lietuvos visuomenès informavimo šaltiniuose, skaičių savižudybės ir pasikèsinimo nusižudyti tema.

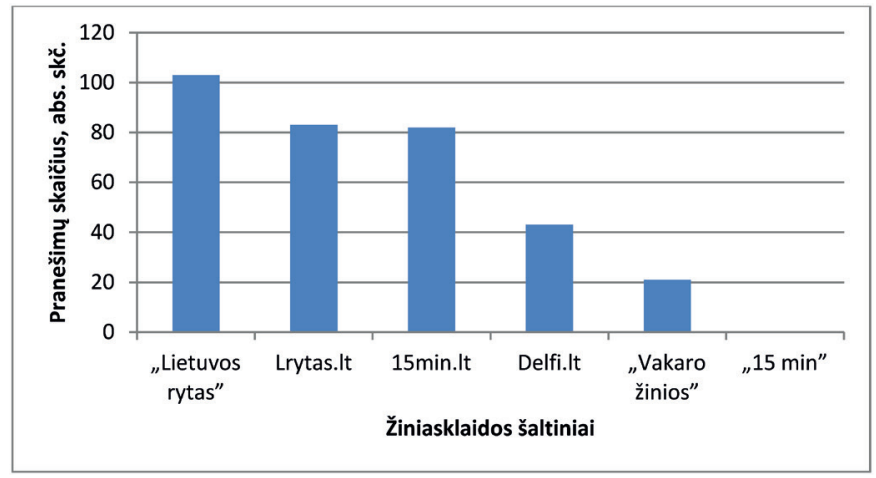

1 pav. Pranešimų apie savižudybę ar bandymą nusižudyti skaičius tirtuose žiniasklaidos šaltiniuose

Daugiausia pranešimų suicidine tema publikavo laikraštis „Lietuvos rytas“. Visiškai nepateikè pranešimų apie savižudybes „15 min“. Tarp internetinių naujienu portalų Lrytas.lt ir $15 \mathrm{~min} . l t$ publikacijas šia tema teikè beveik vienodai, Delfi.lt - šiek tiek mažiau.

Atlikus laikraščiuose ir internetiniuose naujienų portaluose pateikiamų pranešimų turinio analizę ir vertinimą pagal pasirinktus kriterijus, gauti nevienareikšmiški duomenys.

Vienas iš labiausiai dèmesị atkreipiančių dalykų yra publikacijos antraštė. Lyginant laikraščiuose pateikiamų pranešimų antraštes su pateikiamų internetiniuose naujienų portaluose, stebimi gana žymūs skirtumai. Internetiniuose puslapiuose antraštès labiau intriguojančios, ilgesnès, suteikiančios daugiau informacijos (pvz., "Vos 19-kos sulaukusi mergina nusižude savo draugo kieme“, Lrytas.lt, 201311 03, „Akmenès rajone vyriškis dujiniu pistoletu sau šové i galvą", 15min.lt, 20130122 ir pan.) bei jose dažniau vartojamas žodis „savižudybe்“. 
2 paveiksle galima matyti, kad visuose trijuose internetiniuose žinių puslapiuose dažniau minimas žodis „savižudybë“: 15 min.lt - 53, 7 proc., Lrytas.lt 27,71 proc., Delfi.lt - 58,1 proc. straipsnių. Tuo tarpu laikraščių publikacijų antraštès trumpesnès, mažiau informatyvios, bet intriguojančios, siekiančios sudominti („Kodèl palūžo?“, „Lietuvos rytas“, 201303 14, „Moteris ryžosi mirčiai ant bégiü“, „Lietuvos rytas“, 201203 13, „Pasitrauke iš gyvenimo“, „Vakaro žinios“, 201201 20). Nagrinètų laikraščių antraštèse dažniausiai minimas savižudybès metodas - „Lietuvos rytas“ - 19,4 proc., „Vakaro žinios“ - 9,5 proc., antraščių (žr. 2 pav.).



2 pav. Žiniasklaidos šaltiniuose pateikiamų pranešimų antraščių pobūdis, proc.

Beveik pusèje pranešimų internetinèse žinių svetainèse (15min.lt - 42,7 proc., Lrytas.lt - 66,3 proc., Delfi.lt - 48,8 proc.) ir kiek mažiau laikraščiuose („Lietuvos rytas“ - 35,9 proc., „Vakaro žinios“ - 42,9 proc.) pateikiami duomenys, leidžiantys identifikuoti asmenị ir taip ignoruojamos PSO rekomendacijos.

\subsection{Savižudybès aplinkybės, motyvų, būdo ar vietos nurodymas pranešime bei publikacijos pobūdis}

Dauguma pranešimų pateikiami išsamiai, detalizuojant ịvykị. Visuose nagrinètuose žiniasklaidos šaltiniuose yra daugiau nei puse pranešimų, kuriuose nurodomi bent du detalizuojantys aspektai (savižudybès aplinkybės, motyvai, būdas arba vieta). Detaliai ịvykius aprašinèjo, nurodant savižudybių motyvus, būdą ar vietą „Vakaro žinios" - 52,4 proc. 15 min.lt - 72,0 proc., "Lietuvos rytas“ $-83,5$ proc., Delfi.lt - 86,1 proc., Lrytas.lt - 89,2 proc. straipsnių.

Dažnai pranešimai apie ịvykusias savižudybes ar ketinimus nusižudyti turi savo vietą tam tikruose informavimo šaltinio skyreliuose, pvz., „Krašto naujienos“ - „Lietuvos ryte“, „Nelaimès“ - Lrytas.lt. Pagal turinio pobūdị daugumą analizuotų pranešimų apie suicidinị elgesị būtų galima suskirstyti ị dvi grupes: 
1) trumpi, neutralūs pranešimai, kuriuose nurodomi pagrindiniai faktai apie Ł̇vykį; 2) išsamūs, sensacingi, emocingi pranešimai, kuriuose pateikiamas išsamus įvykio vertinimas, nurodoma aplinkybès, motyvai, vertinamas poelgis. Beveik puse pateikiamų pranešimų yra neutralaus, santūraus pobūdžio, aprašomi tik faktai. „Lietuvos rytas“ (59,2 proc.) dažniau rašè sensacingus, savižudybę kaip normalų dalyką ar problemos sprendimo būdą vaizduojančius pranešimus. Lrytas.lt publikuota beveik vienodai pranešimų - 45,8 proc. pranešimų neutralaus, santūraus pobūdžio, o 48,2 proc. - emocingi, sensacingi ar savižudybẻ aprašoma kaip normalus dalykas, problemos sprendimo būdas. Romantizuojančių ar heroizuojančių straipsnių pateikiama mažiau. Dažniausiai tai pranešimai, kuriuose savižudybe išreiškiamas politinis nepasitenkinimas, protestas prieš valdžią ar idealų siekimas. Delfi.lt romantizuojančiai ar heroizuojančiai apie suicidinị elgesị visai nerašè, „Lietuvos rytas“ pateikè tik 1 straipsnị (1,0 proc.), 15 min.lt - 3.66 proc., o Lrytas.lt - 4,8 proc. tokių straipsnių. Taip pat pasitaiko pranešimų apie vykdytus savižudiškus teroro išpuolius, kuriuose smerkiamas suicidinis elgesys.

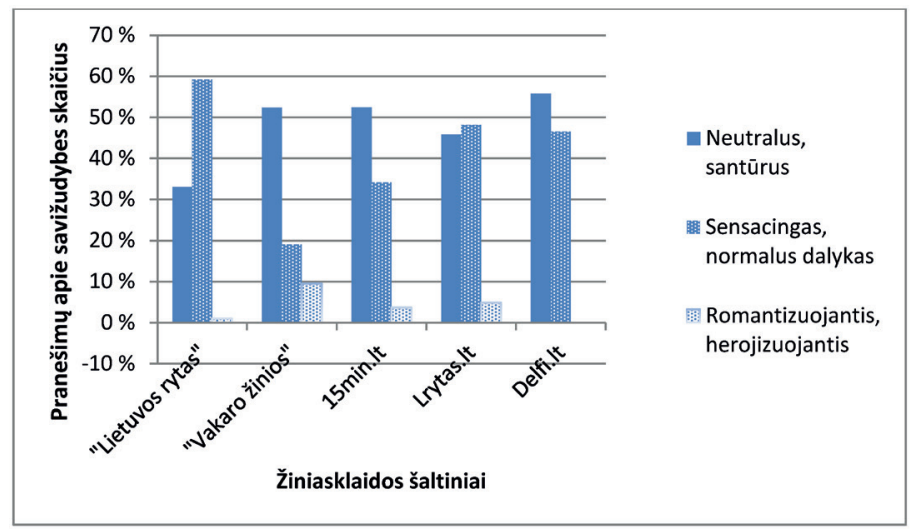

3 pav. Žiniasklaidos šaltiniuose pateikiami pranešimai pagal jų pobūdị, proc.

\subsection{Pranešimų iliustravimas, pateikimo vieta ir nuorodos ị pagalbą}

Kas trečias internetiniuose žinių portaluose savižudybės ar bandymo nusižudyti aprašymas pateikiamas kartu su nuotraukomis ar vaizdo medžiaga (Lrytas.lt - 36,1 proc., Delfi.lt - 31,9 proc.), šiek tiek mažiau 15min.lt - 17,7 proc. Laikraščiuose "Lietuvos rytas“ ir "Vakaro žinios“ apie 10 proc. pranešimų yra pateikiami iliustruoti nuotraukomis. 
Apie žymių, visuomenei žinomų žmonių savižudybes buvo rašoma visuose pasirinktuose informavimo šaltiniuose. Internetiniuose žinių portaluose apie žymių žmonių savižudybes buvo pateikiama daugiau straipsnių, jie dažniau atnaujinami, kartojami. Delfi.lt ir Lrytas.lt pateikè daugiausiai pranešimų apie žymaus žmogaus savižudybę, kiek mažiau 15 min.lt (žr. 4 paveikslą).

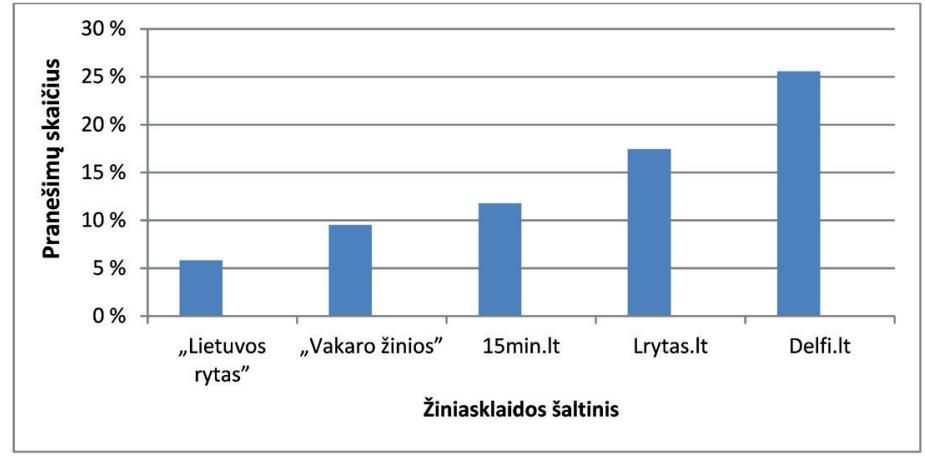

4 pav. Pranešimų apie žymaus žmogaus savižudybę ar bandymą žudytis skaičius, proc.

„Lietuvos rytas“ 19,4 proc. pranešimų apie savižudybes skelbė pirmajame puslapyje, kuriame buvo intriguojantis, trumpas pavadinimas ir nedidelè, poros sakinių pastraipa apie ịvykị su nuoroda ị išsamesnị straipsnị tolesniame laikraščio puslapyje. „Vakaro žinios“ pranešimų pirmuosiuose puslapiuose pateikè mažiau - 9,5 proc.

Nuorodos ị psichologinę pagalbą pateikiamos tik internetiniuose žinių portaluose publikuojamuose pranešimuose. Tokios informacijos nèra laikraščiuose. Tik viename „Lietuvos ryto“ pranešime buvo pateiktos nuorodos ị telefonu teikiamą psichologinę pagalbą. Internetiniai žinių portalai nuorodas pateikia dažniau, tačiau irgi ne visada. Lrytas.lt nuorodas ị psichologinę pagalbą straipsnių apačioje pateikè 61,5 proc. straipsnių, $15 \mathrm{~min} . l t-70,7$ proc., Delfi.lt - 81,4 proc. straipsnių.

\section{Rezultatų aptarimas, diskusijos}

Kaip nurodoma 2008 metų PSO atsakingo pranešimo apie savižudybę rekomendacijose žiniasklaidos profesionalams, straipsnio antraštėje turètų būti vengiama vartoti žodị „savižudybe்", kad būtų sumažinta sensacijos ar normalaus reiškinio pateikimo rizika ${ }^{16}$. İvykio vieta bei metodas taip pat neturètų būti

16 World Health Organization. Preventing Suicide: A Resource for Media Professionals. Geneva: WHO Document Production Services, 2008, p. 9. 
nurodomi nei pačiame pranešime, nei tuo labiau jo antraštèje dèl galimo imitacijos (pamėgdžiojimo) efekto. Tačiau šios rekomendacijos nesilaikoma beveik 60 proc. pranešimų: 30,7 proc. minima „savižudybë“, 17, 9 proc. - savižudybès ar bandymo nusižudyti būdas ir 9,5 proc. - vieta. Chandra su kolegomis pateikia panašius rezultatus - daugumoje straipsnių savižudybės temomis nesilaikoma specialistų teikiamų rekomendacijų atsakingai pateikti informaciją apie savižudybes ${ }^{17}$. Palyginus 1991-2004 metais Klaipedos spaudoje pateiktus pranešimus apie savižudybes, matyti, kad situacija kiek gerẻja: 1991-2004 metais dienraščiuose „Klaipėda“ ir „Vakarų ekspresas“ šiek tiek daugiau nei pusès (54,63 proc.) straipsnių pavadinimuose buvo minimas žodis „savižudybë”, o publikacijų su nurodytu savižudybès būdu pavadinime buvo pateikta penktadalis $(20,01$ proc. $)^{18}$.

Lietuvos žurnalistų ir leidėjų etikos kodekso 49 straipsnyje, kuriame pažymima, kad neturètų būti minimos pavardès ar kitokie asmenị padedantys identifikuoti duomenys, nesilaikoma beveik pusèje (48,6 proc.) straipsnių. Dažniausiai minimos visuomenei žinomų nusižudžiusių ar bandžiusių nusižudyti asmenų pavardès, siekiant sudominti ar suintriguoti skaitytoją. Lietuvoje 2011 metais po visuomenei žinomo žmogaus savižudybès atlikto viešai skleidžiamos informacijos labiausiai lankomuose internetiniuose portaluose tyrimo ${ }^{19}$ rezultatai parodè, kad publikacijų tekstai ir vaizdinè medžiaga neatitinka PSO atsakingo pranešimo rekomendacijų, skirtų žiniasklaidos profesionalams. Taip pat nustatyta, kad per savaitę buvo pateiktos 35 publikacijos šia tema ${ }^{20}$. Apie 2013 metais balandžio ménesị ìvykusią kito žinomo žmogaus savižudybę buvo publikuota 51 straipsnis ir 13 vaizdo reportažų. Higienos instituto Mirties priežasčių registro statistinès informacijos duomenimis, po minètų dviejų savižudybių, savižudybių skaičius, lyginant su ankstesniais mènesiais, ženkliai išaugo.

Pasitaiko ir pranešimų, kuriuose atskleidžiama ir nepilnamečių asmenų tapatybė. P. Skruibis teigia, kad apie nepilnamečių savižudybes reikètų kuo mažiau rašyti arba net išvis neliesti šios temos - tokie rašiniai turi neigiamą poveikị ir gali pasitarnauti kaip savotiška reklama silpnesnès psichikos ir ị savižudybes linkusiems vaikams ${ }^{21}$. Taip pat turètų būti rodomas deramas dèmesys žmonėms,

17 Chandra, P. S.; Doraiswamy, P., et al. Do newspaper reports of suicides comply with standard suicide reporting guidelines? A study from Bangalore, India. The International Journal of Social Psychiatry [interaktyvus]. 2013, Dec 18 [žiūreta 2014-09-02]. <http://www.ncbi.nlm.nih.gov/ pubmed/24351965>.

18 Gedutienè, R.; Maskoliūnaité, L. Savižudybių aprašymo 1991-2004 m. Klaipèdos spaudoje ypatumai. Sociologija. Mintis ir veiksmas. 2005, 2: 131.

19 Jastramskis, D., supra note 8.

$20 \quad$ Ibid.

${ }_{21}$ Nusižudžiusi aštuntokè atsisveikinimo laiško nepaliko (kunigo komentaras). lrytas.lt [interaktyvus]. 2013-05-28 [žiūrèta 201- 02-28]. <http://www.lrytas.lt/lietuvos-diena/nelaimes/ nusizudziusi-astuntoke-atsisveikinimo-laisko-nepaliko-kunigo-komentaras.htm\#nn>. 
patyrusiems netektị dèl savižudybės. Turi būti gerbiamas patyrusių netektị artimųjų privatumas, kadangi šie žmonès patys yra savižudybės rizikoje.

Savižudybės vietos nuotraukos ir filmuota medžiaga neturètų būti naudojama, ypač jeigu tai darant aiškiai parodoma vieta ir metodas. Tai gali turèti ịtakos imitaciniams asmenų veiksmams ${ }^{22}$. Taip pat neturètų būti naudojami nusižudžiusio asmens vaizdai, tačiau, šių rekomendacijų dažnai nesilaikoma. Vietoj to informacijos rengèjai šalia įvykio aprašymo turètų pateikti galimas alternatyvas, kaip atpažinti gresiančios savižudybès pavojų, kokie įmanomi problemos sprendimo būdai, kur gauti pagalbą ${ }^{23}$.

Rekomenduojama nurodyti konkrečias pagalbos galimybes tiek apie savižudybę galvojantiems žmonèms, tiek nusižudžiusiųjų artimiesiems. Tačiau analizuotuose laikraščiuose tokios informacijos visai nebuvo. Galbūt to priežastis vietos spausdintame laikraštyje „taupymas“ ar noras pateikti sensacingą intriguojančią informaciją, o pagalbos kontaktų nurodymas ar būdai, kaip spręsti iškilusias psichologines problemas, nelaikoma verta spausdinti informacija. Internetiniuose puslapiuose nuorodos ị psichologinę pagalbą pateikiamos dažniau, tačiau dažniausiai tai standartiniai šablonai, pasikartojantys daugumoje apie savižudybes spausdinamų pranešimų. Nacionalinės sveikatos tarybos nutarime „Dèl psichikos sveikatos stiprinimo ir psichikos sutrikimų bei savižudybių prevencijos ${ }^{\text {“24 }}{ }^{24}$ Kultūros ministerijai ir Žurnalistų etikos inspektoriaus tarybai siūloma organizuoti žiniasklaidos švietimą, mokymus, mažinant visuomenès informavimo priemonių daromą neigiamą poveikị žmonių psichikai, formuojant negatyvų mąstymą, neigiamas emocijas ir nuotaiką, nes tai turi tiesioginị poveikị ne tik psichikos sveikatos būklei, bet ir savižudybėms, kitokiam destrukciniam elgesiui ${ }^{25}$.

Specialistų ir atsakingų institucijų rekomendacijose nurodoma vengti savižudybę pateikti sensacingai, kaip normalų dalyką ir kaip problemos sprendimą ${ }^{26}$. Išsamūs, emocingi pranešimai skatina įsijausti ị veikèjo vaidmenị, apmąstyti jo poelgio motyvus, atkartoti elgesị $\mathfrak{i}^{27}$, todèl reikètų vengti detalizuoti ịvykị, pateikti jo detales (savižudybès vietą, būdą, motyvus) ${ }^{28}$. Nustatyta, kad žiniasklaidoje

22 Pirkis, J., et al. Reporting of suicide in the Australian media. Australian and New Zealand Journal of Psychiatry. 2002, Volume 36, Issue 2: 157-288.

23 Lietuvos radijo ir televizijos komisijos nutarimas „Rekomendacija viešosios informacijos rengèjams dèl informacijos apie savižudybes pateikimo“, supra note 11.

24 Nacionalinès sveikatos tarybos posedžio nutarimas „Dèl psichikos sveikatos stiprinimo ir psichikos sutrikimų bei savižudybių prevencijos“. 2013, Nr. N-3.

25 Ibid.

26 World Health Organization, "Preventing Suicide: A Resource for Media Professionals" Geneva: WHO Document Production Services, 2008, p. 6.

27 Polukordienè, O. K.. Psichologinés krizés ir ju įveikimas. Praktinis vadovas. Vilnius, 2003, p. 22.

28 Lietuvos radijo ir televizijos komisijos nutarimas „Rekomendacija viešosios informacijos rengèjams dèl informacijos apie savižudybes pateikimo", supra note 11. 
informaciją apie savižudybes pateikiant neatsakingai, per daug išsamiai, vaizdžiai ir nešališkai, pastebima savižudybių daugejjimo tendencija, ypatingai pažeidžiamų žmonių grupeje, nustatomas ryšys tarp amžiaus, lyties ir savižudybės būdo $^{29}$. Labai dažnai savižudybe vertinama kaip tragedija, tragiškas ịvykis, kai nieko nebuvo galima padaryti, kad jo būtų išvengta. Savižudybẻ pateikiama kaip problemos sprendimo būdas, neišvengiamas dalykas. Pasitaiko ir smerkiančio pobūdžio pranešimų, o apie psichologines problemas, jų sprendimo būdus beveik nerašoma. Žiniasklaida galètų atlikti svarbias savižudybių prevencijos ir visuomenès informavimo bei švietimo funkcijas, jei savižudybès atvejai būtų pateikiami santūriai, formuojama nuostata, kad savižudybè nèra vienintelè ir priimtiniausia išeitis iš sunkios situacijos ${ }^{30}$.

Visuose nagrinètuose žiniasklaidos šaltiniuose buvo pateikiami žymių žmonių savižudybių aprašymai, ir visais atvejais tai daroma nesilaikant specialistų rekomendacijų. Dažniausiai nurodoma savižudybès vieta, būdas, galimi motyvai. Pranešimai išsamūs, sensacingi, iliustruoti nuotraukomis iš ịvykio vietos arba gyvenimo momentų. Žymių žmonių savižudybių aprašymai paveikia visuomenę ir skatina Verterio (imitacijos) efekto pasireiškimą ${ }^{31}$.

Apibendrinant galima daryti prielaidą, kad žiniasklaidos atstovai, rašantys ir teikiantys informaciją apie savižudybes ar bandymus nusižudyti, per mažai paiso rekomendacinio pobūdžio dokumentų ir tokiu būdu per mažai prisideda prie visuomenès informuotumą skatinančių politikos priemonių igyvendinimo savižudybių prevencijos ir savižudybių mažinimo srityje. Specialistų parengtos rekomendacijos taikomos tik iš dalies, visai neatsižvelgiama ị rekomendaciją šviesti ir informuoti visuomenę apie psichologinès pagalbos galimybes, prevencines priemones, kaip atpažinti savižudiškų minčių turintị asmenị ir kokią pagalbą jam pasiūlyti. İ rekomendacinio pobūdžio dokumentus mažai teatsižvelgiama. Galima kelti diskusinị klausimą, kodèl taip yra.

Vienas iš veiksnių galètų būti žiniasklaidos siekis sudominti, pritraukti skaitytoją ir taip padidinti savo auditoriją bei gauti didesnę ekonominę naudą. Savižudybės ar bandymo nusižudyti faktas, ypač jeigu jis apie visuomenei gerai žinomą žmogų, gali tapti sensacingos naujienos vertu ịvykiu, pritraukiančiu didelę skaitytojų auditoriją. Dažnai pelno nesiekiančios organizacijos tokio pobūdžio temomis pranešimų neteikia. To pavyzdys yra tyrime analizuotas nemokamas savaitraštis „15min“, kuriame pasirinktu laikotarpiu nebuvo nė vienos publikacijos savižudybès tema.

29 Sisask, M.; Varnik, A. Media Roles in Suicide Prevention: Systematic Review. International Journal of Environmental Research and Public Health. 2012, 9 (1): 123-138.

30 Nacionalinès sveikatos tarybos posedžio nutarimas „Dèl psichikos sveikatos stiprinimo ir psichikos sutrikimų bei savižudybių prevencijos", supra ote 24 .

31 Niederkrotenthaler, T., et al. Role of media reports in completed and prevented suicide: Werther v. Papageno effects“. The British Journal of Psychiatry. 2010, 197(3): 234-43. 
Dar vienas veiksnys - tai Lietuvos visuomenèje vyraujančios nuostatos. Savižudybè dažnai traktuojama kaip galimas problemos sprendimo būdas, žmogaus teisė pasirinkti ar neišvengiamas dalykas, išeitis iš susiklosčiusios padèties. Todèl žiniasklaidos publikacijose savižudybės aprašymų pobūdis, kai suicidinis elgesys pateikiamas kaip normalus dalykas, daugumai visuomenès yra priimtinas.

Taip pat žiniasklaidos atstovus būtina šviesti dèl savižudybių temos pateikimo žiniasklaidoje pasekmių, supažindinti išsamiau su psichikos sveikatos specialistų teikiamomis rekomendacijomis, kaip tinkamai pranešti apie savižudybes ir kokių pasekmių gali turèti netinkamas informacijos publikavimas. Kultūros ministerija, Žurnalistų etikos inspektoriaus tarnyba turètų sudaryti žurnalistams reguliacijos ir savikontrolès sistemas dèl informacijos apie savižudybes pateikimo, o žiniasklaidos „priežiūros atstovams“ sekti netinkamus, netikslius, pernelyg supaprastintus ar sensacingus savižudybių aprašymus.

Ir galiausiai, nèra aiškios politikos ir teisiškai ịtvirtintų konkrečių ir detalių faktų apie savižudybes pateikimo reikalavimų žiniasklaidai. I specialistų rekomendacijas galima žiūrèti pasirinktinai, laisvai, nes nèra teisinio pagrindo. Paliekama patiems žurnalistams ir leidejjams spręsti, kokio turinio publikacijas ir vaizdo medžiagą pateikti visuomenei. Lietuvos Respublikos Seimas ir Vyriausybė galètų ịstatymu reglamentuoti, kaip tinkamai teikti informaciją savižudybių ar bandymų nusižudyti tema, bei kontroliuoti jų laikymąsi. Desouza ir Lin siūlo atkreipti dèmesị i ị̂rodymais grindžiamą politiką, kuri skirta organizacijoms, ir įrodymais informuojančią politiką, orientuotą ị asmenis bei skatinančią jų motyvaciją ${ }^{32}$. Žiniasklaidos dẻka viešoji nuomonè galètų būti pamažu keičiama, imitacijos efekto būtų galima išvengti, tinkamai reaguojant, informuojant visuomenę, profesionaliai pateikiant informaciją apie ịvyki, ir taip prisidèti prie savižudybių mažinimo politikos šalyje.

Žiniasklaidai rekomenduojama skelbti informaciją ar publikacijas apie išsamiai išnagrinètus politinius sprendimus arba nutarimus dèl savižudybių prevencijos ir taip efektyviai prisidèti prie savižudybių prevencijos ir politikos formavimo.

\section{Išvados}

1. Populiariausiuose Lietuvos žiniasklaidos šaltiniuose vyrauja sensacingi, emocingi, išsamūs ir siekiantys pritraukti skaitytoją savižudybių ar bandymų nusižudyti aprašymai. Nesilaikant rekomendacijų, dažnai nurodomi su savižudybe ar bandymu nusižudyti susijusio asmens duomenys (48,6 proc.), būdas ar vieta

32 Desouza, K. C.; Lin, Y. Towards Evidence-Driven Policy Design: Complex Adaptive Systems and Computational Modeling. The Innovation Journal: The Public Sector Innovation Journal. 2011, Volume 16(1), Article 7: 1-19. 
(58,0 proc.), straipsnių antrašteje vartojamas žodis „savižudybe““, internetiniuose portaluose kas trečias pranešimas iliustruotas nuotraukomis ar vaizdo medžiaga, o laikraščiuose apie 10 proc. pranešimų pateikiami pirmuosiuose puslapiuose.

2. Specialistų parengtos rekomendacijos taikomos tik iš dalies, visai neatsižvelgiama ị rekomendaciją šviesti ir informuoti visuomenę apie psichologinès pagalbos galimybes, prevencines priemones, kaip atpažinti savižudiškų minčių turintị asmenị ir kokią pagalbą jam pasiūlyti. Dažnai pasinaudojama visuomenei žinomo žmogaus savižudybe ir pateikiama sensacinga, intriguojanti naujiena.

3. Tarptautiniuose ir nacionaliniuose dokumentuose atkreipiamas demesys $i$ žiniasklaidos atstovų mokymo reikalingumą, mažinant visuomenės informavimo priemonių daromą neigiamą poveikị žmonių psichikai. Tačiau Lietuvos žiniasklaidos atstovai, rašantys ir teikiantys informaciją apie savižudybes ar bandymus nusižudyti, per mažai paiso specialistų rekomendacijų.

\section{Literatūra}

1. Bohanna, I.; Wang, X. Media guidelines for the responsible reporting of suicide: a review ofeffectiveness. Crisis [interaktyvus]. 2012, 33 (4) [žiūrèta 2014-01-26]. <http:// www.ncbi.nlm.nih.gov/pubmed/22713977>.

2. Centers for Disease Control and Prevention, National Center for Injury Prevention and Control. Web-based Injury Statistics Query and Reporting System (WISQARS) [interaktyvus]. [žiūrèta 2014-02-22]. <www.cdc.gov/ncipc/wisqars>.

3. Chandra, P. S.; Doraiswamy, P., etc. Do newspaper reports of suicides comply with standard suicide reporting guidelines? A study from Bangalore, India. The International Journal of Social Psychiatry [interaktyvus]. 2013, Dec 18 [žiūrèta 201409-02]. <http://www.ncbi.nlm.nih.gov/pubmed/24351965>.

4. Desouza, K. C.; Lin, Y. Towards Evidence-Driven Policy Design: Complex Adaptive Systems and Computational Modeling. The Innovation Journal: The Public Sector Innovation Journal [interaktyvus]. [žiūrèta 2014-01-21]. <http://www.innovation.cc/ scholarly-style/desouza_lin_policy_informatics_v16ila7.pdf $>$.

5. Fu, K. W.; Jip, P. S. Changes in reporting of suicide news after the promotion of the WHO media recommendations. Suicide Life Threat Behav. 2008, Oct. 38(5).

6. Gedutienè, R.; Maskoliūnaitė, L. Savižudybių aprašymo 1991-2004 m. Klaipèdos spaudoje ypatumai. Sociologija. Mintis ir veiksmas. 2005, 2: 128, 131.

7. Gemius Baltic [žiürèta 2014-02-29]. <http://www.e-lietuva.net/2013/01/29/lankomiausi-tinklapiai-lietuvoje-2012-metu-pabaigoje/>.

8. Jastramskis, D. Savavališkos mirties paskatos žurnalistikoje. Žurnalistikos tyrimai. Komunikacija ir informacija. 2012, 5: 32.

9. Kusta, A. Savižudybiu aprašymai gali paskatinti savižudybę. Jaunino psichologinès pagalbos centras [interaktyvus]. [žiūrèta 2014-03-01]. <http://www.jppc.lt/?p=140\& lng $=$ lt $>$.

10. Lietuvos radijo ir televizijos komisijos nutarimas „Rekomendacija viešosios informacijos rengèjams dèl informacijos apie savižudybes pateikimo". Lietuvos radijo ir televizijos komisija [interaktyvus]. 2011, Nr. N-20 [žiūrèta 2014-02-29]. <http://www. 
rtk.lt/lt/teises_aktai/kiti_teises_aktai/rekomendacija_viesosios_informacijos_ rengejams_del_informacijos_apie_savizudybes_pateikimo>.

11. Lietuvos Respublikos kultūros ministerija, Viešosios informacijos rengèjų ir skleidèjų duomenų bazė [žiūrèta 2014-0-09]. <http://www.lrkm.lt/go.php/lit/Visuomenes_ informavimo_politika/206>.

12. Lietuvos Respublikos Vyriausybès 2005 m. gegužès 13 d. nutarimas Nr. V-401 „Dèl savižudybių prevencijos 2003-2005 metų programos patvirtinimo“. Valstybès žinios. 2005, Nr. 36-1575.

13. Lietuvos žurnalistu ir leidejų etikos kodeksas. Vilnius, 2005.

14. Life Line. Crisis Support, Suicide Prevention, Statistics on Suicide in Australia. [interaktyvus]. [žiūrèta 2014-02-22]. <https://www.lifeline.org.au/About-Lifeline/ Media-Centre/Suicide-Statistics-in-Australia/Suicide-Statistics $>$.

15. Nusižudžiusi aštuntokè atsisveikinimo laiško nepaliko (kunigo komentaras). lrytas.lt [interaktyvus]. 20130528 [žiūrèta 2014-02-28]. <http://www.lrytas.lt/lietuvos-diena/nelaimes/nusizudziusi-astuntoke-atsisveikinimo-laisko-nepaliko-kunigo-komentaras.htm\#nn>.

16. Nacionalinès sveikatos tarybos posėdžio nutarimas „Dèl psichikos sveikatos stiprinimo ir psichikos sutrikimų bei savižudybių prevencijos" [interaktyvus]. 2013, Nr. N-3 [žiūrèta 2014-02-28]. <www3.lrs.lt/docs2/JFMGPSXQ.DOC>.

17. Niederkrotenthaler, T., et al. Role of media reports in completed and prevented suicide: Werther v. Papageno effects. The British Journal of Psychiatry. 2010, Sep. [interaktyvus]. 197(3): 234-43 [žiūrèta 2014-02-28]. <http://www.ncbi.nlm.nih.gov/ pubmed/20807970>.

18. Pirkis, J., et al. Reporting of suicide in the Australian media. Australian and New Zealand Journal of Psychiatry. April 2002, Volume 36, Issue 2: 157-288.

19. Polukordienè, O. K. Psichologinès krizès ir ju ịveikimas. Praktinis vadovas. Vilnius, 2003, p. 22.

20. Ramadas, S.; Kuttichira, P. The development of a guideline and its impact on the media reporting of suicide. Indian Journal of Psychiatry [interaktyvus]. 2011, 53(3). [žiūrèta 2014-09-02]. <http://www.ncbi.nlm.nih.gov/pubmed/22135440>.

21. Sisask, M.; Varnik, A. Media Roles in Suicide Prevention: Systematic Review. International Journal of Environmental Research and Public Health. 2012, 9 (1): 123138.

22. Scott, A.; Guo, B. For which strategies of suicide prevention is there evidence of effectiveness? HEN synthesis report. World Health Organization, 2012, 33 p.

23. Skruibis, P.; Bagdonienè, M. Rekomendacijos rašantiems apie savižudybes [interaktyvus]. [žiūrèta 2014-01-25]. <http://tylazudo.lt/uploads/manager/file/Rekomendacijos-zurnalistams.pdf $>$.

24. Suicide Prevention, Awareness, and Support, NON-PROFIT Organization and Website <http://www.suicide.org/suicide-statistics.html $>$.

25. World Health Organisation, Suicide Prevention and Special Programs $<$ http://www. who.int/mental_health/prevention/suicide/suicideprevent/en/>.

26. World Health Organization. „Preventing Suicide: A Resource for Media Professionals“ Geneva: WHO Document Production Services, 2008. 


\title{
Expresion of Recommendations on Suicide about Responsible Report in Lithuanian Media
}

\author{
Kristina Balevičiūtè \\ Vilnius Public Health Center, Lithuania \\ Aldona Jociutè \\ Mykolas Romeris University, Lithuania
}

Summary. The article reveals the policy of promoting public awareness of suicide prevention and its expression in the media. The article analyzes how the reports of suicide and suicide attempts in Lithuanian press and internet portals follow to the specialists recommendations to inform and educate the public about suicide and psychological support as well as opportunities of prevention. It also analyzes whether the recommendations of the nature of the report are taken into account, whether the report is illustrated by photographs or video material, is there mentioning of the person identification data in the report, and whether the report is about famous people suicide or suicide attempt of a famous person. The content analysis of the reports was based on the Lithuanian Journalists and Publishers Ethics Code and the 2008 WHO report on responsible suicide guidelines for media professionals. Three largest Lithuanian circulation newspapers and the most visited websites were selected for the research.

WHO suicide prevention specialists and psychologists have developed guidelines for journalists and publishers how to responsibly develop and disseminate information about the suicide. Recommendations can change the writing style and thus protect from imitation syndrome. However, only in partnership providing consultations and training to the development the maximum benefit will be achieved.

The study showed that recommendations of professionals are partially applied. The recommendations to educate and inform the public about the potential psychological assistance, preventive measures, how to recognize a person with suicidal thoughts and to offer him any help are completely ignored. A name of a famous person is frequently used, and it is provided as an intriguing and sensational news. In the most popular Lithuanian's media sources, sensational, emotional, detailed and attempting to attract the reader of suicide or suicide attempts descriptions dominate.

Keywords: policy of suicide prevention, message about suicide in the media, responsible informing, public awareness.

Kristina Balevičiūtè, Vilniaus visuomenès sveikatos centro Visuomenès sveikatos saugos kontrolès skyriaus vyriausioji specialistė, Mykolo Romerio universiteto Politikos ir vadybos fakulteto Politikos mokslų instituto magistrantè. 
Kristina Balevičiùtè, Vilnius Public Health Center Public health Safety Control Senior Specialist; Mykolas Romeris university, Faculty of Policy and management, Master student of Institute of Political Science.

Aldona Jociutė, Mykolo Romerio universiteto Politikos ir vadybos fakulteto Politikos mokslų instituto lektoré, biomedicinos mokslų daktarè. Mokslinių tyrimų kryptys: visuomenès sveikatos politika ir vadyba, sveikatos stiprinimas ir ugdymas, sveikatos stiprinimo vertinimas.

Aldona Jociutè, Mykolas Romeris university, Faculty of Policy andmanagement, lecturer at the Institute of Political Science, Doctor of Biomedicine. Research interests: public health policy and management, health promotion and education, health promotion assessment. 